Techniques \& Culture

Revue semestrielle d'anthropologie des techniques

9 | 1987

Des idées pour observer

\title{
Renouer le fil
}

\section{François Sigaut}

\section{(2) OpenEdition}

\section{Journals}

Édition électronique

URL : https://journals.openedition.org/tc/858

DOI : $10.4000 /$ tc. 858

ISSN : 1952-420X

Éditeur

Éditions de l'EHESS

Édition imprimée

Date de publication : 1 septembre 1987

ISSN : 0248-6016

Référence électronique

François Sigaut, «Renouer le fil », Techniques \& Culture [En ligne], 9 | 1987, mis en ligne le 23 janvier 2006, consulté le 29 septembre 2022. URL : http://journals.openedition.org/tc/858 ; DOI : https:// doi.org/10.4000/tc. 858

Ce document a été généré automatiquement le 29 septembre 2022.

Tous droits réservés 


\section{Renouer le fil}

François Sigaut 